\title{
GENDER ANALYSIS ON SLANG LANGUAGE IN STUDENTS DAILY CONVERSATION
}

\author{
Kasmawati Amir \\ Universitas Islam Negeri Alauddin Makassar \\ kasmawatiamir466@gmail.com \\ St. Azisah \\ Universitas Islam Negeri Alauddin Makassar \\ siti.azisah@uin-alauddin.ac.id
}

\begin{abstract}
This research aimed at finding out the gender analysis on slang language used by the eight semester students of English Education Department in their daily conversation at UIN Alauddin Makassar. The researcher applied qualitative descriptive research. The participant of this research was the eight semester students of English Education Department at UIN Alauddin Makassar which consisted of 10 students. The participants were taken by using purposive sampling technique which consisted of 5 male students and also 5 female students. The data were collected through interviews and observations. The result of the data indicated that slang language used by the eight semester students of English Education Department in their daily conversation were slang in theater, art slang, public school or university slang as well as society slang. Besides, the male and female slang language was different caused of some factors such as situation and condition, age and politeness, as well as gender itself. There was a significant difference between male and female students' percentage in using slang language. The mean score of male percentage in using slang language (66.48) while female only (33.50).Based on the finding and discussion of the research, the researcher drew a conclusion that male and female students of English Education Department used slang language in different way and also frequency.
\end{abstract}

Keywords: Gender, Slang, Kinds of slang

\section{A. INTRODUCTION}

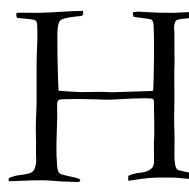

uman being is communal people. They interact with other people and their neighborhood in social context. In Interacting with other people, they use language. Language has an important function to all society who used it, because language is a way to interact one to another person especially in a communication. Finocchiaro in Ba'dulu (2009:1) stated that language is a system of arbitrary, vocal symbol which permits all people in a given culture, or other people who have learned the system of that culture, to communicate or to interact.

That statement told how important language was, the tool of communication that people always used in their daily conversation even activity. All of people in this world used their own language, because every single country had national language as an identity or characteristic to distinguish them from others. Generally, Standard English had known as international language used for all of people in this world to communicate each other. Nowdays, there were many variety of languages which was usually used by some people or group of people in their daily conversation. In social relationship, language was used by someone to represent who they were. It related with strong identity of a certain social group and it was represented by slang. Hartmann \& Stork as cited by Alwasilah (1985: 57) stated that: 
Slang is a variety of speech characterized by newly coined and rapidly changing vocabulary, used by the young or by social and professional groups for 'in-group' communication and thus tending to prevent understanding by the rest of the speech community.

According to the quotation, slang indicated non-standard language that was known by the certain social group and not only used by young but also professional. Generally, most of countries had their own slang terms in their language. For instance, in Indonesia, slang was found in daily conversation and most of people use it, such as 'cupu' (old-fashioned), 'pace' (father), 'mace' (mother), 'lebay' (exaggerate), etc. Eventhough Indonesia had their own slang language, most of Indonesian was still influenced to use English slang in their daily conversation such as bro, awesome, buddy, bingo, faceache, hacker, macho, awright!, aye-aye, easy down, etc.

Based on the preliminary observation which was conducted by the researcher on May $15^{\text {th }}$ 2016 in UIN Alauddin Makassar, the researcher found that slang was commonly spoken by the students of English Education Department in their daily conversation. Most of the students whether male or female, enjoyed talking with their friends used slang language than standard language. Eventhough they used slang in their daily conversation but the researcher also found that male and female students had different frequency in slang usage. These data had inspired the researcher to investigate more about the differences slang language used by male and female students.

This issue was in line with the data which was founded by some researchers that males and females had differences in conversational style. 'Male speakers often use tabooed words and slang in their daily speeches. To be exact, tabooed words and slang can be found more frequently in men's language than in women's, though they are of the same educational level' (Ning, Dai \& Zhang 2010: 127). The different ways of male and female speak were already known in sociolinguistic study as gender. Crowley \& Himmelweit (1994: 58) stated that:

'Gender' refers to the way, in particular society, people are socially constructed to behave and experience themselves as 'women' or 'men'. Although all societies appear to treat women and men differently and thus have some notion of gender, what is consists of varies enormously from one society to another.

The relation between gender and language was always being interesting topic to be discussed. Dealing with slang as non-standard language, it was very interesting to investigate whether male or female students often use slang in their daily conversation. Referring to some previous explanations above, the researcher excited to conduct a descriptive qualitative research tittled " Gender Analysis on Slang Language Used by the Eight Semester Students of English Education Department in Their Daily Conversation at UIN Alauddin Makassar".

\section{B. LITERATURE REVIEW}

Generally, the issue of the influence of gender on slang usage was not remarkably very new. So far, there had been some studies about the relationship between gender and its influence with the slang usage. This issue had been observed and researched by many studies with different 
aspects and models for sure. Hence, many findings, which had coherent views with this study, had been already published in society.

First, Salma (2013: 67) found that the number of slang words used frequently by males is 488 occurrences while the number of slang words used by the females is 410 occurrences. The data also revealed that the most frequent slang words that were used among teenagers are acronym, loan or borrowing, and substation. To compare this, the main concern of my research was focused on the frequency of slang words used by males and females students in their daily conversation at the university and it emphasized the global slang words. Second, Shahraki \& Rakesh (2011: 201) stated that in the first and third age groups, males used slang words and expressions more than females. Male display, by using these expressions, their toughness, representing their masculinity society required of them; in contrast, females usually are more cautions than males in their choices of styles. As the conclution, a various of researchers' findings above described that gender can influenced the students' word choice and slang usage which indicated male used slang more frequently than female in their daily conversation.

\section{Gender}

Talking about gender, we must be thinking about men and women. But actually there were lots of definitions from expert who explain what gender was.

Crowley \& Himmelweit (1994: 6) stated that Gender refers to the differences between 'women' and 'men' which are socially constructed, whereas sex refers to the biological distinction between 'females' and 'males'. In other page, they gave explanation that 'Gender' refers to the way, in particular society, people are socially constructed to behave and experience themselves as 'women' or 'men'.

Besides Ning \& Dai (2010: 127) stated that 'Gender' refers to set of qualities and behaviors expected from a female or male by society. What is more, gender roles are learned and can be affected by factors such as education or economics. To me, this opinion had reinforced the first opinion above that gender was quality or behavior of male and female to distinguish their masculinity or feminist in society. Here the society had big influence to create female or male concept of gender. Other opinion was coming from Robeyns cited by Azizah (2012: 13) defined gender as follows:

Gender is a social position that men and women occupy. A person belongs to a gender because she is thought to have certain bodily features that reveal her reproductive capacities. These bodily features function as markers for evaluating individuals as either men or women, and for justifying their respective social position.

That statement explained that gender was social setting which was including relation system, keeping grew in its function to define men and women or masculine and feminine as well as to arrange the relationship between people and society.

\section{Slang}

Now days, the existence of slang already spread in society. Many people used it in their daily conversation. It was very interesting to know what slang deeply. There are many definitions of slang, Spolsky (2008: 35) stated that: 
... Slang is as special kinds of 'intimate' or in-group speech. Slang is a kind of jargon marked by its rejection of formal rules... slang is associated with peer group and gang speech, intentionally used to obtain some degree of secrecy.

From this opinion, the researcher understood that slang was one of the kinds of the language which was growing up from some group or gang speech to distinguish them from another language. It also explained from the others expert related to definition of slang as newly language from group of people. Pei and Gaynor cited by Alwasilah (1985: 56) stated that:

Slang is a style of language in common use, produced by popular adaptation and extension of the meaning of existing words and by coining new words with disregard for scholastic standards and linguistics principles of the formation of words; generally peculiar to certain classes and social or age groups.

From that explanation had argued that slang language was one kind of language that was very popular in some people or group of people which was commonly used in certain social kevel and age groups. This slang language was different from standard language that already known by people in generally because slang was new formation of language which had special characteristic.

\section{Kinds of Slang}

There are many types or kinds of slang are commonly used by society. But Eric Partridge cited by Hanggoro (2011: 10-20) mentioned 10 types of slang. Ten of them are:

a. Cockney slang

The term of the Cockney slang refers to working-class people in London, especially for east London. It often uses in reference to the Cockney accent. And Cockney slang is the brightest in England because it has a very pronounces accent. There are two kinds of cockney slang, at first, Cockney slang that spoken by educated and middle class people. At second, Cockney that used by the semi literate and illiterate people, it called as Cockney London of the street.

b. Public house slang

Public house group of words and phrases makes up for the smallness of the recorded vocabulary by the nature of the subject. It is genial, cheery, materialistic, but not gross nor cynical.

c. Workmen's slang

This type has a link with the public house slang. It is very closely allied to tradesmen's slang and also considered by people's activity in working. Most of the users of workmen's slang are laborers either town and farm laborers.

d. Tradesmen's slang 
In tradesmen's slang as in workmen's slang, some of words are related to origin slang and the users are the worker too, but the difference is the tradesmen's slang considers four as typical: tailors, butchers, chemist, and builders. Slang in art

e. Slang in commerce

This type of slang is often used for commerce, because much of modern commerce depends on publicity, a firms needs that catchy phrase or rhymes that can impress the public

f. Society slang

There is much slang in the colloquial speech of society, most of words soon disappear, but a considerable number of them make good their place in ordinary speech. Moreover, slang in society shows a joyously or jauntily over the object and the practice of slangster's own calling.

g. Slang of commerce

This slang used in trade the words are closely related to the trade of commerce. It is often use by businessmen, mostly used in stock exchange.

h. Slang in public school and university

The slang that used in university is considerable different with public school slang, when boys leave school and go to the university, they need to drop the old slang and to mould themselves to the slang of the university. Growing boys and high spirited young fellows detest restraint of all kinds, and prefer making a dash at life in slang phraseology of their own to all the set forms and syntactical rules of alma mater.

i. Slang in theatre

In nineteenth century, the theater began to exercise a powerful influence on ordinary and interest spoken English and theatrical slang gradually gained a status in the first part.

\section{RESEARCH METHOD}

In this research, the researcher conducted qualitative descriptive research (case studies). Qualitative research seeks to understand the what, how, when, and where of an event or an action in order to establish its meaning, concepts, and definition, characteristics, metaphors, symbols, and descriptions (Angrosino in Latief, 2014: 75). Case study was a qualitative strategy in which the researcher explores in depth a program, event, activity, process, or one or more individuals.

This research would be started on January, 2017 in UIN Aalauddin Makassar, Regency of Gowa. This research included some the eight semester students of English Education Department.

Participants were defined as some people who would be questioned related to the problem statements which were going to obtain. Participants of this research were 10 of students from the $8^{\text {th }}$ semester students of English Education Department of UIN Alauddin Makassar. There were 5 males' student and also 5 females' student as respondent in interview session while collecting data was conducted. 
The techniques that researcher used to get a valid data were observation, and interview. Observation was needed to collect the data such as the slang words that are often used in the students' daily conversation. The observation was held in 4 days by using field a note of the students' conversation in UINAlauddin Makassar.

The places of the observation were in the campus area, such as class, library, cafeteria, and dormitory. Besides observation, the researcher also conducted Interview. Interview was a process question and answering session by interviewer and interviewee related to the problem and information that was going to be obtained.

In this research, the technique of data analysis used by researcher was adopted from Miles \& Huberman in Sugiyono (2009: 338) have divided into three steps those are data reduction, data display and conclusion or drawing/ verification.

In order to determine the percentage of each slang classification, the researcher needed to compute the numerical data by the using a simple scaling composed by Thorsten in Salma (2013:33).

$$
\mathrm{P}=\frac{\mathrm{F} \times 100 \%}{\mathrm{~N}}
$$

Explanation:

P: Percentage

F: Frequency

N: Overall Number

And also the researcher calculated the mean score of male and female students' percentage in using slang language by using the formula:

$$
\overline{\mathrm{x}}=\frac{\sum \mathrm{x}}{\mathrm{n}}
$$

Explanations :

$\bar{x}$ : Mean score

$\sum \mathrm{x}$ : Sum of all values

$\mathrm{n}$ : Number of values

(Woodbury, 2002:48)

\section{FINDINGS AND DISCUSSIONS}

\section{Findings}

The researcher has conducted the interview and deeply observation about gender analysis on slang language used by the eight semester students of English Education Department in their daily conversation at UIN Alauddin Makassar. The result showed that there were some different 
of slang language used by male and female students, not only the kinds of slang but also the frequency of slang language usage in their daily conversation.

a. Kinds of slang language used by the students of English Education Department in their daily conversation at UIN Alauddin Makassar

Based on the interview has been conducted by the researcher, the data showed that whether male and female used slang language in their daily conversation. Most of the interviewee felt enjoy to speak slang language eventhough they did not know what kind of slang language they used.

From interviews section, the researcher found slang words that frequently used by the eight semester students of English Education Department such as gonna, wanna, what's up, dude, come on, guys, hang out, burry up, sis, bro, bullshit, yolla, salty, gimme, dunno, gotta, hastag, feeling blue, get up and also impolite words like fuck, bitch, shit and holy shit. The similar data also found by the researcher in observations section related to slang words used by the students frequently in daily conversation such as buddy, what the bell, come on, gonna, have a good vibes, bro, fucking, gotta, wanna, holy shit, feeling blue, sis, guys, shit, fucking, lemme, what's up, bent, mother fucker, fucker, gonna, got up, break it up, goofy, rookie, pig out, bae, selfie, wefie, awesome, hang out, and lemme.

Dealing with the data of interview, the researcher found that most of interviewees did not know about the kinds of slang language which they used in their daily conversation. They just adopted and imitated some slang words which were they got from movies especially American movie, English songs as well as internet. The researcher underlined some words which indicated the kinds of slang language frequently used by the students. The key words were "movie, music and internet".

The word "movie" had close meaning with drama and theater. Besides, the word "music" was one of kind of art and "internet" was one of the universal or public access used by people or society all around the world. Those assumptions were interpreted by the researcher that the kinds of slang language used by students are slang in theater, slang in art and society slang. Even though they also used university slang as the background of participants were students. Based on those data, the researcher interpreted that slang language which the eight semester student of English Education Department used in their daily conversation were slang in theater, art slang, society slang, as well as public school or university slang.

b. The differences of slang language between male and female students' of English Education

\section{Department}

The data from interview showed that male and female students had many differences in using slang words. Based on data interview, the researcher elaborated the answers of tenth interviewee by asking the slang words they often used in their daily conversation. The female students answered some words slang they used were "burry up, get up, bro, is, feeling blue, guys, gimme, what's up, gonna, wanna, dunno, selfie, wefie, and fuck". 
In other hand, male students gave the different answer with the same question. They more frequently use slang words such as "dude, bullshit, holy shit, fuck, come on, what's going on, bitch, salty, and yolla" eventhough they also used slang words like the female used such as "dunno, wanna, gonna, gimme, what's up, selfie, groupie, and feeling blue". Meanwhile, the differences of slang words used by male and female students also had founded in the data of observation. At the first observation which was conducted on February $9^{\text {th }} 2017$ at the Tarbiyah and Teaching Science Faculty area, the researcher noted some slang words used by male students such as "buddy, what the hell, come on, gonna, have a good vibes, bro, fucking, gotta, wanna and holy shit" while the female students only spoke little slang words like "feeling blue, gonna, sis, guys and what the bell".

At the second observation which was conducted on February $13^{\text {rd }} 2017$ also showed that male students used cruel slang words such as "what the hell, shit, bro, fucking, bro, lemme, what's up" while female students just used slang words like "gonna and fucking". Besides, the male students more frequently used slang words in the third observation on February $15^{\text {th }} 2017$ such as "what's up, guys, bro, bent, mother fucker, fucker, fucking, gonna, got up, and boly shit" than female students only used little slang language such as "break it up and gonna".

But in the last observation which was conducted on February $20^{\text {th }} 2017$, whether male and female used many slang words. For the male students, they used some words such as "goofy, rookie, pig out, bae, break it up, wanna" while female students used more slang words such as "sis, guys, gonna, selfie, wefie, come on, awesome, hang out, wanna, what's up, lemme". From those data, the researcher concluded that male and female students had different way and style in using slang language.

c. The percentage of slang language used by male and female students of English Education Department

Based on the data of observation, the researcher had found that there was the different percentage of slang language usage between male and female students of English Education Department. The data showed that male were more frequently used slang language than female. In the first observation which was conducted on February $9^{\text {th }} 2017$ showed that male spoke slang language in $76.19 \%$ rather than female students used slang language only $23.80 \%$ in a day. Besides, the data showed the increasing frequency of slang usage by male in the second observation which was conducted on February $13^{\text {rd }} 2017$ up to $83.33 \%$ while female spoke slang language only $16.66 \%$ In the third observation which was conducted on February $15^{\text {th }} 2017$ showed that the slang language usage by male was in high percentage until $85 \%$ and for female only $15 \%$ in a day.

Meanwhile in the last observation which was conducted on February $20^{\text {th }} 2017$, female students spoke slang language more frequently than male students. The percentage until $78.57 \%$ while for male only $21.42 \%$ in a day. The last observation showed the contrast data than three observations earlier.

Moreover, to find the data of male and female slang language percentage, the researcher also accumulated the percentage of slang language used by male and female students. The research also calculated the mean score of percentage of slang language used by the male and 
female students. The data showed that the mean score of male percentage of slang language usage was $66.48 \%$ while female only $33.50 \%$.

\section{Discussion}

The researcher discussed about the kinds of slang language used by the eight semester students of English Education Department, and the differences of slang language used by male and female students as well as the percentage of slang language usage in their daily conversation. Those discussions were clarified as follow:

a. Kinds of slang language used the students of English Education Department in their daily conversation at UIN Alauddin Makassar

Eric Partridge cited by Hanggoro (2011: 10-20) mentioned 10 types of slang which were cockney slang, public house slang, workmen's slang, tradesmen's slang, slang in art, slang in commerce, society slang, slang of commerce, slang in public school and university, and slang in theatre.

Based on findings, the researcher also found some kinds of slang language used by students. Whether male or female used slang language in their daily spoken. In observation process, the researcher noted some slang language used by the students such as buddy, what the bell, come on, gonna, have a good vibes, bro, fucking, gotta, wanna, boly shit, feeling blue, sis, guys, shit, fucking, lemme, what's up, bent, mother fucker, fucker, gonna, got up, break it up, goofy, rookie, pig out, bae, selfie, wefie, awesome, hang out, and lemme.

Those slang words had analyzed by the researcher then classified the kind of each them. Some slang words which frequently used by students always found in movie especially in American movie such as what's up, what's going on, what the hell, dude, come on, bullshit, shit, bitch, fucking, mother fucker, boly shit, as well as buddy. Those words usually used by the students even they did not know the kind because they just adopted from movie. The word "movie" had closer meaning with drama and theatre. So, the researcher assumed one of the kinds of slang words used by male and female students was slang in theatre.

Besides, the other slang words used by students were classified as art slang because that slang frequently found in some English song, those were wanna, dunno, gimme, lemme, gotta, gonna, yolla, and also rude word like fuck or fucking. They also used public school and university slang such as bro, sis, bangout, burry up, feeling blue and guys. The other kind of slang words used by the students was society slang because many society used those slang such as selfie, wefie, hastag, bro, sis, bent, have a good vibes, groupie, rookie, goofy and bae.

Based on those data, the researcher interpreted that slang language which the eight semester student of English Education Department used in their daily conversation were slang in theatre, art slang, society slang, as well as public school or university slang.

b. The differences of slang language between male and female students' of English Education

Department 
According to Dai \& Zhang (2010: 127) male had different topic while talking with female. They stated that Slang word or tabooed topic including criminality, vulgar language more frequently used by male. While for female, they usually talked about certain topic like fashion, relationship, cosmetics etc. This opinion had proven by the researcher when conducting observations. At the first observation which was conducted on February $13^{\text {rd }} 2017$, the researcher noted some vulgar slang words used by male students such as what the hell, fucking, and holy shit. While female students used more polite slang words such as feeling blue, sis, and gonna.

At the second observation which was conducted on February $13^{\text {rd }} 2017$ also showed that male students used cruel or vulgar slang words such as "what the hell, shit, bro, fucking, bro, lemme, what's up" while female students just use slang words like "gonna and fucking". Besides, the male students more frequently used slang words in the third observation on February $15^{\text {th }} 2017$ such as "what's up, guys, bro, bent, mother fucker, fucker, fucking, gonna, got up, and boly shit" than female students only used little slang language such as "break it up and gonna". But in the last observation which was conducted on February $20^{\text {th }}$ 2017, whether male and female used many slang words. For the male students, they used some words such as "goofy, rookie, pig out, bae, break it up, wanna" while female students used more slang words such as "sis, guys, gonna, selfie, wefie, come on, awesome, bang out, wanna, what's up, lemme".

Those data indicated that male students were used more cruel and vulgar slang language than female students. Comparing with the theory has mentioned in chapter 2, Reik (1954: 14) affirmed that "we all know that there is a 'man talk' and a 'woman talk". He observed that "men . . . will not hesitate to say 'Hell' or 'Damned.'. . . Women will rarely say 'It stinks' preferring to state that it has a bad smell". Lakoff (1973) observed that men use stronger expletives such as shit and damn, whereas women use weaker or softer profanity such as oh dear, goodness, or judge.

The differences between male and female using slang language were influenced with some factors. The factors would be discussed as follow:

1) Situation and condition

The first factor was situation and condition. Whether male and female used slang language had to consider many aspects include situation and condition. What the researcher meant by situation was formal and informal situation. While condition meant the participant's feeling when using slang words or language. In interview sections, the researcher asked about the situation and condition of interviewee when using slang language. Six of ten interviewees had similar arguments about the situation and condition they used slang. They admitted that "...about the situation and condition, sometimes I speak slang language when I am meeting with my classmate or with my un-English also".

Another interviewee answered "...Yeah about the situation, I mean we need to consider the situation whether it is formal or informal. It's depend on with whom I am speaking to, so when I speak with my close friend, I am going to use slang language because the situation will be funnier and you get unique response from your friends when you use slang language. But when I 
met with my lecturer and my parents, I am going to use formal language or Standard English". Other interviewee added "... when I am feeling happy sometimes also when I am angry. It is depends on my situation and my feeling..." the last arguments explained that the interviewee used slang “... when I am shock or my friend surprise me, I will say "what the fuck you, holy shit, bullshit, come on get out from myself, don't disturb me, fuck you bitch".

From those data, the researcher concluded that male and female students considered about the situation and condition whether it was formal or non formal situation. It was influenced the way they speak slang words or language in their daily conversation.

2) Age and politeness

The second factor was age. Based on the data of interview, the researcher found that age was one of the big influences on slang usage by male and female students. It was proven by the interviewee arguments which stated that "...I have to see the target first, if I talk with male but old than me, automatically I have to use Standard English because it is impolite to use Slang language. But with male and have the same age, yeah automatically I use slang..."

This argument in line with the interviewee background as a Muslim student which had many knowledge and considerations with the politeness and the way he spoke to the older or younger people around them.

3) Gender

The last and most important factor which was influenced slang language used by male and female students' of English Education Department was gender. To obtain the data about the relation between slang language and gender, the researcher asked some question to the interviewee in interview sections which were "do you speak slang language for same gender or different gender? Do you prefer to speak slang language only for male or female? And why do you prefer to speak slang language with male or female?"

The researcher found several arguments from interviewee. Four from five male students agreed that they spoke slang language with male and female but they were more prefer to speak slang language with the same gender (male) while one of male students only spoke slang language with same gender. For the reason, the male felt free to speak slang language with same gender as they stated "we are free to share one another even though it is the secret things and the women is forbidden to know... I can tell them something freely rather than when I am speaking to women or female". The other reason from male why they prefer to speak slang with same gender because male were not bring feeling hardly like female as the interviewee mentioned "... because male is hard to bring feeling. It is different with female when they speak they always bring feeling".

Meanwhile, the researcher also analyzed the female arguments related to the question which was asked to them in interview sections. The data from interview showed that four from five female students spoke slang language not only for the same gender but also with different gender but they preferred to speak slang language with same gender (female), while there was also female students only spoke slang language only for the same gender(female). They mostly 
had same reason why they spoke slang language with female rather than male as they stated "... because we are female think that when we speak slang for different gender like male, it looks like impolite" in other reason they also cared about male feelings as they taught "...yeah, we don't know how the male's feelings when we say "fuck, shit" to him. But when we say those words for the same gender, it's okay, they will understand us..."

These data showed that gender had big influence on slang language used by students. Whether male and female students were consider with whom they spoke to. Male were freely to speak slang language with the same gender (male also) and female preferred to speak slang language also with female (same gender). From those explanation, the researcher concluded that slang language which were used by male and female students influenced with some factors, not only situation and condition included the place, the feeling, formal or informal, but also related to with whom they spoke to and also consider about the politeness and the age of people around them.

c. The percentage of slang language used by the male and female students of English Education Department

There were some previous studies about the different percentage of slang language used by male and female. One of them was Salma (2013: 67) found that the number of slang words used frequently by males is 488 occurrences while the number of slang words used by the females is 410 occurrences. It was dealing with the data which founded by the researcher in observation process.

In the first observation which was conducted on February $9^{\text {th }} 2017$ showed that male spoke slang language in $76.19 \%$ rather than female students used slang language only $23.80 \%$ in a day. At the second observation on February $13^{\text {rd }} 2017$, the percentage of slang usage by male increased until $83.33 \%$ while female spoke slang language only $16.66 \%$. At the third observation on February $15^{\text {th }} 2017$ showed that the slang language usage by male was in highest percentage until $85 \%$ and for female only $15 \%$ in a day. But in the last observation on February $20^{\text {th }} 2017$, The percentage of slang language used by female up to $78.57 \%$ while for male only $21.42 \%$ in a day.

Moreover, the researcher also calculated the mean score of percentage of slang language used by the male and female students in their daily conversation. The data showed that, the mean score of male percentage of slang language usage is $66.48 \%$ while female only $33.50 \%$. This result answered the third problem statement of this research that male were more frequently speak slang language than female in their daily conversation.

\section{E. CONCLUSION AND SUGGESTION}

\section{Conclusion}

Based on the results of the research findings and discussion, the researcher concluded three points based on the research questions that had been described above as follows: 
a) Based on the data from interview, the researcher concluded that all of the interviewee did not know about the kinds of slang language which were they used in their daily conversation. They just adopted and imitated some slang words which were they got from movies especially American movie, English songs as well as internet. Then, the researcher interpreted that slang language which the eight semester student of English Education Department used in their daily conversation were slang in theater, art slang, public school or university slang as well as society slang.

b) Slang language which were used by male and female students were different and it caused of some factors, not only situation and condition including the place, the feeling of participant, formal or informal, but also related to with whom they spoke to and also considered about the politeness and the age of people around them

c) Male were more frequently spoke slang language than female in their daily conversation. It was proved with the result of calculating the mean score of percentage of slang language usage of male and female in four times of observation. The data showed that, the mean score of male percentage of slang language usage was $66.48 \%$ while female only $33.50 \%$.

\section{Suggestion}

After finishing the study about Gender Analysis on Slang Language Used by the Eight Semester Students of English Education Department in Their Daily Conversation at UIN Alauddin Makassar, the researcher, tried to give essential suggestion for the future researcher.

As this study had the limit, there were some developments of research needed for the perfection of this study. This study could be developed by the future researchers by conducting the other studies dealing with gender analysis on slang language. By using this study as the resource, the researcher hoped this study could be developed in purpose of conducting the good research about the influences of gender on slang language in students' speaking English ability.

\section{REFERENCES}

Alwasilah, Chaedar,(1985). Sosiologi Bahasa, First Edition. Bandung: Angkasa..

Azizah, Siti, (2012). Gender Mainstreaming in Education: Case Studies of Islamic Primary Schools in South Sulawesi, Indonesia 2000 - 2006, Victoria University. 2012.

Azizah, Siti, (2016). et al, Kontekstualisasi Gender, Islam dan Budaya, First Edition. Makassar: Alauddin University Press. 2016.

Azizah, Siti Nurpahmi. S, (2016). Potret Gender dalam Buku Pelajaran Bahasa Inggris Siswa MTSN BAlang-Balang. Alauddin University Press.

Awaliah, I. M. (2017). Gender Issues In Charlotte Bronte's Jane Eyre. ETERNAL (English, Teaching, Learning, and Research Journal), 3(1), 107-117.

Ba'dulu, Abdul Muis, Introduction to Linguistics, First Ediction. Makassar: Badan Penerbit Universitas Negeri Makassar. 2009. 
Coates, Jennifer,(1973). Women, Men and Language: A sociolinguistics account of gender differences in language, Second Edition. London: Longman and Imprint of Pearson Education.

Crowley, Helen and Himmelweist Susan, (1994). Knowing Women: Feminism and Knowledge, First Edition. United Kingdom: Polity Press.

Epoge, N.P, (2012).Slang and Colloquialism in Cameroon English Verbal Discourse, International Journal of Linguistics ISSN 1948-5425, 2012, Vol. 4, No. 1

Golafshani, N, (2003). Understanding Reliability and Validity in Qualitative Research. The Qualitative Report,8(4), 2003, 597-606. Retrieved fromhttp://nsuworks.nova.edu/tqr/vol8/iss4/6

Lakoff, R (1973). Language and Woman's Place. Language in Society.

Latief, Mohammad Adnan, (2014). Research Methods on Language Learning: An Introduction, Second Edition. Malang: UM Press.

Lips, Hilary M, (1992). Sex \& Gender: An Introduction, Second Edition. California: Mayfield Publishing Company.

Miles, M. B. \& Huberman, A. M. (1984) Qualitative Data Analysis: A Sourcebook of New Methods. California; SAGE publications Inc.

Ning, Haiiang \& Dai, Xue, (2010). On Gender Difference in English Language and Its Causes. Asian Social Science, 2010, Vol. 6. No. 2, p 127

Oxford Dictionary, (2008). Definition of Slang, Fourth Edition: Oxford University Press.

Reik, T. (1954). Men and Women Speak Different Languages. Psychoanalysis.

Salma, Annisa, (2013). Gender Influence on Slang Used by Teenagers in Their Daily Conversation at School, 2013, Passage vol. 1, no. 2, h. 63-70, download on July 27, 2016 < $\underline{\text { http://ejournal.upi.edu/index.php/psg/article/view/538> }}$

Shenton, AK, (2004). 'Strategies for Ensuring Trustworthiness in Qualitative Research Projects', Education for Information 2004, vol. 22, no. 2, pp. 63-75.

Shahraki, Sara Hashemi \& Rakesh, Abbas Eslami, (2011). Check This One Out: Analyzing Slang Usage Among Iranian Male and Female Teenagers. Englosh Language Teaching. 2011. Vol. 4. No.2. p.201

Spolsky, Bernard, (2004). Sociolinguistics, Third Edition. United Kingdom: Oxpord University Press.

Sugiyono, (2009). Metode Penelitian Pendidikan Pendekatan Kuantitatif, Kualitatif, dan R\&D. Bandung: Alfabeta.

Sugiyono, (2013) Cara Mudah Menyusun: Skripsi, Tesis, dan Disertasi, Second Edition. Yogyakarta: Alfabeta. 
Volume 3, Number 02, December 2017

Thorne, Tony.(2005). Dictionary of Contemporary Slang, $3^{\text {rd }}$ edition, London: A\&C Black.

Trumble, W. and Stevenson, A (eds. (2002).) Shorter Oxford Shorter Dictionary, 5th edition, New York: Oxford University Press.

Wahyuni, S \& Rosa, R. N, (2003). Types of Word Formation $f$ Slang Words Found in Tv Advertisement, 2003, English Language and Literature E-Journal / ISSN 2302-3546

Woodbury, George. (2002). Introduction to Statistics. Canada: Wadsworth Group.

Zhou, Yanchun \& Fan, Yanhong, (2013) A Sociolinguistic Study of American Slang, Theory and Practice in Language Studies, vol. 3, no. 12, p. 2210. 